\title{
THE INFLUENCE OF DILUTION OF SERUM ON ITS OPSONISING POWER. ${ }^{1}$
}

\author{
By William E. Marshall, M.B., Ch.B., D.P.H., Assistant Bacteriologist, \\ Lister Institute of Preventive Medicine.
}

(Plates XXXVIII.-XLI.)

RECENT contributions by Dean and by Simon, Lamar, and Bispharn have drawn attention to the importance of the dilution of the serum on its opsonising power. Dean found that the dilution of fresh, unheated, normal human serum was not accompanied by any fall in the phagocytic power until a quarter concentration had been reached, and he also found that the points corresponding to the $\frac{1}{4}, \frac{1}{8}$, $\frac{1}{16}$, and $\frac{1}{32}$ dilutions of normal human serum lay on a parabola which showed that the phagocytosis was proportional to the square root of the serum concentration.

Simon, Lamar, and Bispham, on the other hand, using a different method of estimating phagocytic power, found great variations in the results obtained on the dilution of the sera of normal individuals and of animals of the same species.

In the experiments to be described the ordinary method of Wright. and Douglas was used, the diluent employed being normal saline solution. The number of leucocytes counted was never less than fifty, and the slides were so arranged that the counter was quite unaware which slide he was counting.

The following experiments were undertaken to show the effect in such dilution experiments of the injection of large doses of killed bacteria :-

\section{Influence of the Dilution of the Normal Serum of the Rabbit and of the Ox on Phagocytosis.}

Five different experiments with normal rabbit serum and human leucocytes, the micro-organism used being the Staphylococcus pyogenes aureus, gave the following results :- 


\begin{tabular}{|c|c|c|c|c|c|c|c|c|c|c|}
\hline & & & & \multicolumn{7}{|c|}{ Concentration of Serum. } \\
\hline & & & & 1 & 0.5 & $0 \cdot 25$ & 0.125 & 0.0625 & 003125 & 0.015625 \\
\hline \multirow{6}{*}{ Phagocytosis } & Rabbit & & . & 1 & 0.991 & 0.943 & $0 \cdot 761$ & 0.477 & 0.305 & $0 \cdot 186$ \\
\hline &, & 2 & . & 1 & $1 \cdot 003$ & 0.953 & 0.580 & 0.327 & $0 \cdot 176$ & 0.133 \\
\hline & , & 3 & . & 1 & 0.894 & 0.546 & 0.479 & $0 \cdot 290$ & $0 \cdot 156$ & $\ldots$ \\
\hline & & & $\cdot$ & 1 & $0 \cdot 731$ & 0.717 & 0.307 & $0 \cdot 158$ & $0 \cdot 081$ & $\ldots$ \\
\hline & $"$, & 5 & . & 1 & $1 \cdot 014$ & 0.877 & 0.566 & 0.444 & $0 \cdot 200$ & 0.012 \\
\hline & \multicolumn{2}{|c|}{ Average } & . & 1 & $0 \cdot 910$ & 0.773 & 0.483 & $0 \cdot 304$ & $0 \cdot 153$ & 0.072 \\
\hline
\end{tabular}

Seven different experiments with normal ox serum, using as before human leucocytes and Staphylococcus pyogenes aureus, gave the following results :-

\begin{tabular}{|c|c|c|c|c|c|c|c|c|c|}
\hline & & & & & & ncentrat & ion of $\mathrm{Se}$ & run. & \\
\hline & & & 1 & 0.5 & $0 \cdot 25$ & $0 \cdot 125$ & 0.0625 & 0.03125 & 0.015625 \\
\hline & $(\mathrm{O} \times \mathrm{I}$. & . & 1 & 1.006 & 0.683 & 0.545 & 0.369 & $\ldots$ & $\ldots$ \\
\hline & ," 2 . & - & 1 & $0 \cdot 785$ & 0.961 & 0.684 & 0.709 & $\ldots$ & $\ldots$ \\
\hline & " 3. & . & 1 & 0.952 & 0.458 & 0.506 & $0 \cdot 211$ & $\ldots$ & $\ldots$ \\
\hline Phagocytosis &,, 4 . & . & 1 & 0.956 & 0.674 & 0.676 & 0.325 & $\ldots$ & $\ldots$ \\
\hline &,, 5 & . & 1 & $1 \cdot 147$ & 0.972 & $0 \cdot 289$ & 0.345 & $\ldots$ & $\ldots$ \\
\hline &, 6. & . & 1 & 0.698 & 0.701 & 0.536 & 0.395 & $\cdots$ & $\ldots$ \\
\hline & $(, 7$. & . & 1 & 1.020 & 0.707 & 0.318 & 0.383 & $\ldots$ & $\ldots$ \\
\hline & Average & . & 1 & 0.937 & 0.736 & 0.507 & 0.391 & $\ldots$ & $\ldots$ \\
\hline
\end{tabular}

The dilution of the normal serum of these two animals evidently differs from the dilution of normal human serum, as there is usually a distinct fall in the phagocytosis on one-half concentration of the serum. The two curves obtained (Plate XXXVIII. Chart I.), with rabbit serum and ox serum, practically coincide, and I am indebted to my colleague, J. C. G. Ledingham, for demonstrating to me that these correspond to a logarithmic curve which satisfies the equation $1.98 y=\log$. $100 x$, or, in other words, the phagocytosis is a linear function of the logarithm of the concentration.

In a few preliminary experiments on the dilution of the normal unheated human serum with staphylococci and tubercle bacilli my results were similar to those obtained by Dean, which have been referred to in the beginning of this paper.

25一,IL. OF PATH.-VOL. XII. 
II. Effect produced upon the Normal Rabbit Serum Curve by the Intravenous InJeCtion of LARGe DOSES OF KILLED Staphylococcus pyogenes aureus.

ExPERIMEnT 1.-Rabbit E.-This rabbit was injected intravenously with three agar tubes of killed Staphylococcus pyogenes aureus, and bled twenty-four hours after inoculation. The phagocytosis obtained on the dilution of the serum gave the following result:-

$\begin{array}{llllllll}\text { Concentration of serum . } & 1 & 0.75 & 0.5 & 0.25 & 0.125 & 0.0625 & 0.03125 \\ \text { Phagocytosis . . . } & 1 & 0.71 & 0.51 & 0.14 & 0.24 & 0.30 & 0.20\end{array}$

giving the curve shown in Plate XXXVIII. Chart II.

Experiment 2.-Rabbit $M$.- This rabbit was injected intravenously with five agar tubes of killed Staphylococcus pyogenes aureus on 23rd May, and again with three agar tubes on 24th May. It was bled on 25th May, twentyfour hours after the second injection. The opsonic index for Staphylococeus pyogenes aureus, compared with normal Rabbit $\mathrm{C}$, was $0 \cdot 70$, and the dilution of the serum gave the following:-

$\begin{array}{llllllllll}\text { Concentration of serum . } \quad . \quad & 1 & 0.75 & 0.5 & 0.33 & 0.25 & 0.125 & 0.0625 & 0.03125\end{array}$

$\begin{array}{llllllllll}\text { Phagocytosis . . . . } & 1 & 0.32 & 0.21 & 0.21 & 0.057 & 0.008 & 0.059 & 0.049\end{array}$

giving the curve shown in Plate XXXIX. Chart III.

Experiment 3.-Rabbit S.-This rabbit received intravenously twelve agar tubes of killed Staphylococcus pyogenes aureus, and was bled at intervals of one hour, five hours, and twenty-five hours after the injection. The opsonic indices at these intervals were $1.32,1 \cdot 37$, and 0.71 respectively, the serum of normal Rabbit $\mathrm{C}$ being used as the control. The results obtained on the dilution of the serum at these intervals were as follow :-

\begin{tabular}{|c|c|c|c|c|c|c|c|c|c|}
\hline & \multicolumn{8}{|c|}{ Concentration of Serum. } \\
\hline & & 1 & 0.75 & 0.5 & 0.33 & 0.25 & $0 \cdot 125$ & 0.0625 & 0.03125 \\
\hline \multirow{3}{*}{ Phagocytosis } & After 1 hour & 1 & $0 \cdot 73$ & 0.36 & $0 \cdot 15$ & $0 \cdot 18$ & 0.05 & 0.04 & 0.08 \\
\hline & $" 5, "$ & 1 & 0.75 & $0 \cdot 47$ & 0.51 & $0 \cdot 24$ & 0.15 & 0.07 & $0 \cdot 05$ \\
\hline &,, $25 \quad$, & 1 & 0.38 & 0.49 & 0.30 & 0.40 & 0.12 & 0.04 & 0.06 \\
\hline
\end{tabular}

giving the curve seen in Plate XXXIX. Chart IV.

EXPERIMENT 4.-Rabbit $Z$.-This rabbit received intravenously ten agar tubes of killed Staphylococcus pyogenes aureus, and was bled twenty hours after injection. The opsonic index, compared with Rabbit C, was $1 \cdot 36$, and the opsonic index for the tubercle bacillus $0 \cdot 67$. Dilution of the serum with both these micro-organisms gave the following figures :-

$\begin{array}{ccccccc}\text { Concentration of serum . . } & 1 & 0.5 & 0.25 & 0.125 & 0.0625 & 0.03125 \\ \begin{array}{c}\text { Phagocytosis of Staphylococcuss } \\ \text { pyogenes aureus . . . . }\end{array} & 1 & 0.37 & 0.10 & 0.10 & 0.09 & 0.13 \\ \text { Phagocytosis of tubercle bacillus } & 1 & 0.82 & 0.77 & 0.76 & 0.57 & 0.36\end{array}$

giving the curves shown in Plate XL. Chart V. 
There seems little doubt, from the foregoing experiments, that the injection of the large doses of killed Staphylococcus pyogenes aureus has a marked effect on the phagocytic curve of normal serum for that organism. There is a quick and rapid fall in the opsonising power of the serum. This phenomenon appears to be limited to the micro-organism injected, as with the tubercle bacillus a curve corresponding to the normal was obtained. The opsonic index of the undiluted serum gives no indication how the curve will go, some rabbits with a low opsonic index giving a normal curve (Rabbit $\mathbf{S}$ before injection gave an opsonic index of 0.56 , and Rabbit $\mathrm{M}$ before injection gave an opsonic index of $0 \cdot 70$ ). On the other hand, after the injection of large doses of killed bacteria, some rabbits gave a comparatively high opsonic index; nevertheless, on diluting the serum a marked fall in the phagocytic curve was obtained, and, compared with the normal rabbit curve, the opsonic index varied at each dilution.

\section{Influtence of the Dilution of Immune Serum upon Phagocytosis.}

Rabbit B, having being immunised with numerous subcutaneous injections of killed Staphylococcus pyogenes aureus, was bled thirteen days after the last injection, and the phagocytosis on dilution was as follows:-

$\begin{array}{lllllllll}\text { Concentration of serum } & . & . & 1 & 0.5 & 0.25 & 0.125 & 0.0625 & 0.03125 \\ \text { Phagocytosis . . } & . & . & 1 & 0.61 & 0.50 & 0.65 & 0.52 & 0.51\end{array}$

It was again bled five days afterwards, i.e. eighteen days after the last injection, when the following figures were obtained:-

$\begin{array}{llllllll}\text { Concentration of serum } & 1 & 0.75 & 0.5 & 0.25 & 0.125 & 0.0625 & 0.03125 \\ \text { Phagocytosis . . . . } & 1 & 0.91 & 0.79 & 0.72 & 0.63 & 0.84 & 0.62\end{array}$

The opsonic index on both occasions was less than unity-in the first instance being 0.71 , and in the second 0.97 , and the curves obtained are shown in Plate XL. Chart VI.

In the experiments on the dilution of the immune serum the most striking phenomenon was the good phagocytosis obtained even on the thirty-second dilution of the serum,-in fact, the phagocytosis did not in the one case fall below 50 per cent. of the maximum, while in the other it never fell below 60 per cent. of the maximum. Compare this with the normal curve, where, on the thirty-second dilution of the serum, the phagocytosis is 25 per cent. of the maximum.

Immune Horse (Rich).- - This horse, during a long period of time (about two years), immunised with the staphylococcus, was also tested, and the dilution of the serum gave the following:-

$\begin{array}{lllllllll}\text { Concentration of serum } & 1.0 & 0.75 & 0.5 & 0.33 & 0.25 & 0.125 & 0.0625 & 0.03125 \\ \text { Phagocytosis } & 0.42 & 0.81 & 1.0 & 0.66 & 0.52 & 0.46 & 0.30 & 0.13\end{array}$

The opsonic index compared with normal horse (Clipper) serum was so low, 0.51 , and the enormous increase in the opsonising power on the half concentration of the serum was so striking, that it seemed desirable to repeat the experiment. Accordingly this horse was again bled one week afterwards, and on this occasion the following figures were obtained :-

$\begin{array}{llllllllll}\text { Concentration of serum } & . & 1.0 & 0.75 & 0.5 & 0.33 & 0.25 & 0.125 & 0.0625 & 0.03125 \\ \text { Phagocytosis . . } & . & 0.52 & 0.51 & 0.62 & 0.87 & 1.0 & 0.37 & 0.15 & 0.23\end{array}$

The opsonic index, compared with normal (cart-horse) serum, was 0.62 , and on this occasion the maximum phagocytosis was obtained on the $\frac{1}{4}$ dilution of the serum. The curves are shown in Plate XLI. Chart VII. 
Another peculiarity about this immune serum was that it contained no demonstrable thermostable immune substance, nor, as the following figures will show, could it be complemented by the addition of fresh normal serum. In both these respects it differed from the serum of the immune Rabbit B.

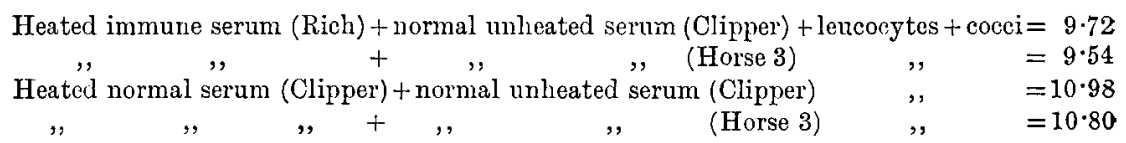

Heated Immune Serum (Rablit B).-As it seemed desirable to determine the effect upon phagocytosis of the dilution of the thermostable substance present in immune sera, the serum of Rabbit $\mathrm{B}$ was heated to $60^{\circ} \mathrm{C}$. for about twenty-five minutes, and the following results were obtained on dilution:-

$\begin{array}{lllllllll}\text { Concentration of serum } & . & 1.0 & 0.75 & 0.5 & 0.25 & 0.125 & 0.0625 & 0.03125 \\ \text { Phagocytosis . } & . & 0.61 & 0.73 & 1.0 & 0.62 & 0.84 & 0.77 & 0.56\end{array}$

giving the curve seen in Plate XLI. Chart VIII.

This demonstrates that the thermostable substance in immune serum stands dilution very well, and it is probably the presence of this substance in unheated immune serum which causes the marked phagocytosis in the high dilutions of that serum. The anomalous eurves obtained with the serum of the immune horse (Rich), however, are difficult to explain, and the absence of thermostable substance is also interesting, as the serum of this horse in the early stage of immunisation was proved to contain thermostable amboceptor (Dean). This condition is somewhat analogous to that observed in the late stages of diphtheria immunisation, where the animal, though quite resistant to large doses of the toxin, is incapable of producing antitoxin in high concentrations.

Further experiments are necessary, however, and some theoretical points arising from a consideration of the results obtained in this paper will be dealt with in a future communication on this subject.

\section{CONCLUSIONS.}

1. The dilution of the fresh unheated serum of the ox and of the rabbit causes a gradual diminution in its opsonising power.

2. The points corresponding to the $\frac{1}{2}, \frac{1}{4}, \frac{1}{8}, \frac{1}{16}$, and $\frac{1}{32}$ dilutions of these normal sera lie on a logarithmic curve, which shows that the phagocytosis is a linear function of the logarithm of the concentration.

3. The intravenous injection of large doses of killed staphylococci entirely alters the form of this curve, the phagocytosis falling quickly to a minimum.

4. The dilution of the serum of an animal immunised against the Staphyloccus pyogenes aureus is not accompanied by any marked fall in the opsonising power even at the thirty-second dilution of the serum.

5. That the opsonic index of the undiluted serum is no guide to the manner in which a serum will behave on dilution. It is probable that the amount of immune substance in the serum can be better determined by the dilution method outlined in this paper. 

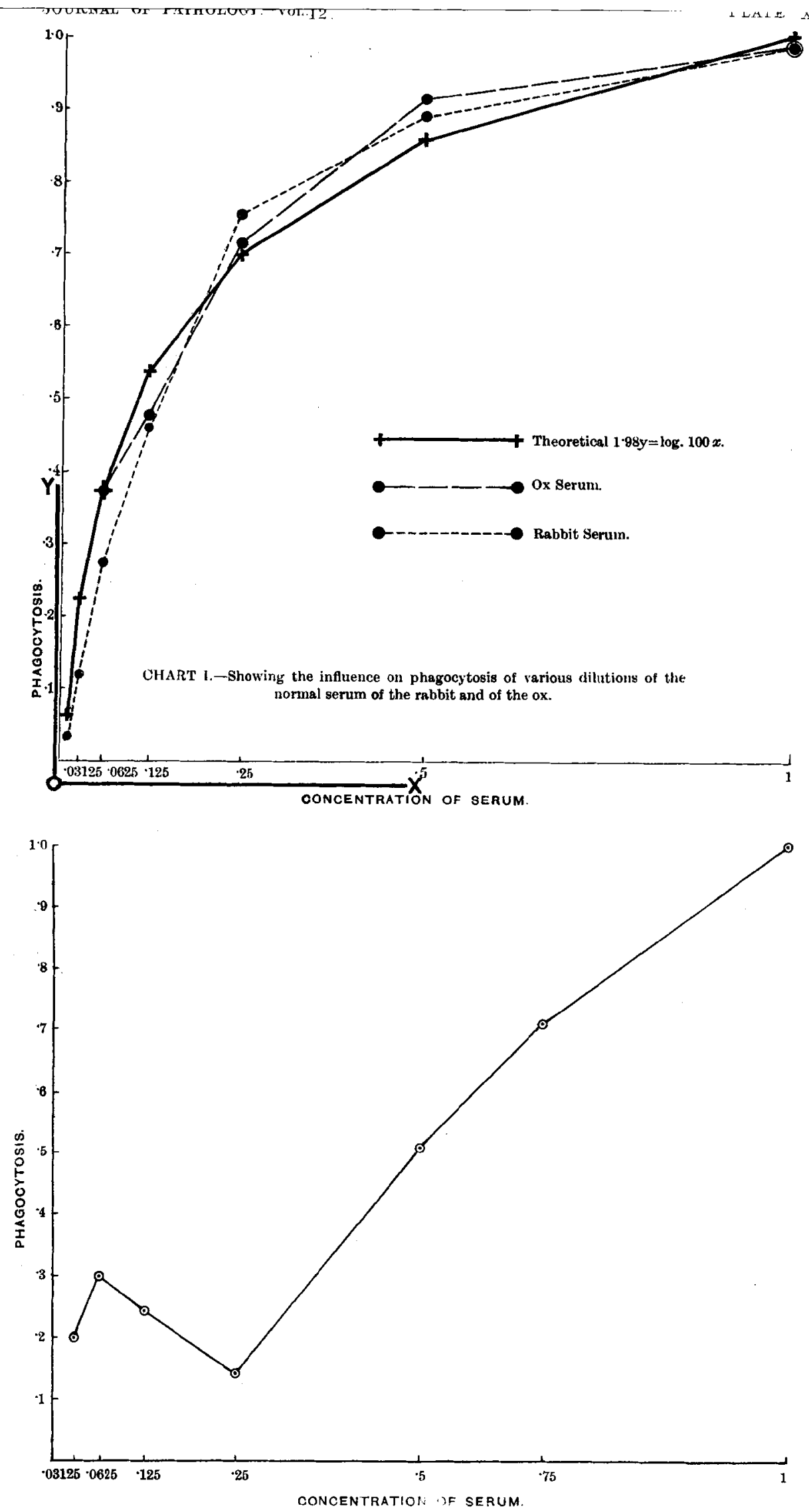

CHART II.-Rabbit E, showing the phagocytosis in the presence of various dilutions of the serum twenty.four hours after intravenous injection with three agar tubes of killed Staphylococcus pyogenes aureus. 


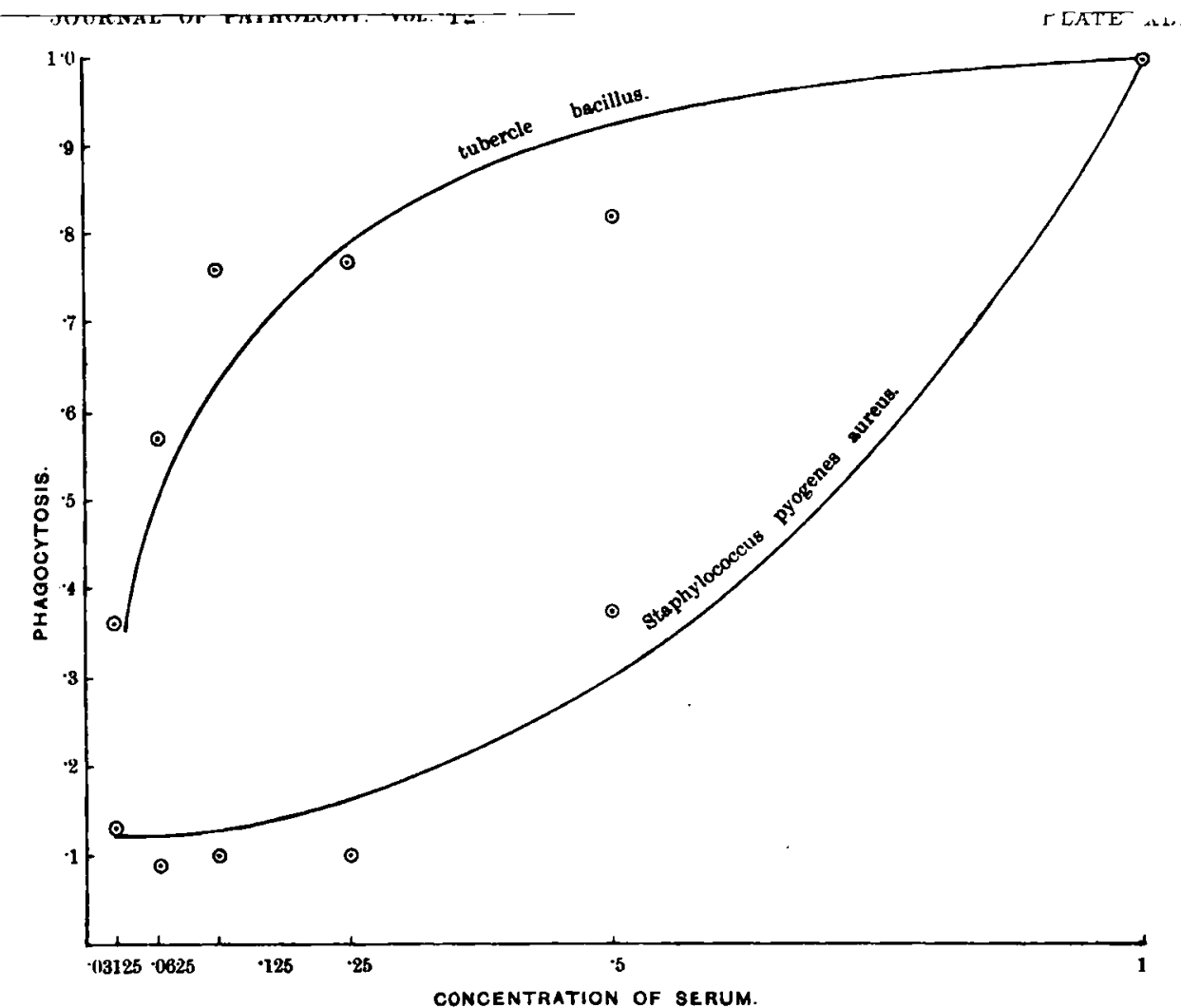

CHART V.-Rabbit Z, showing the phagocytosis in the presence of various dilutions of the serum twenty hours after the intravenous injection with ten agar tubes of killed staphylococcus pyogenes aureus. Opsonic Index for the tubercle bacillus $=0.07$, and for the Staphylococcus pyogenes aureus $=1 \cdot 86$.

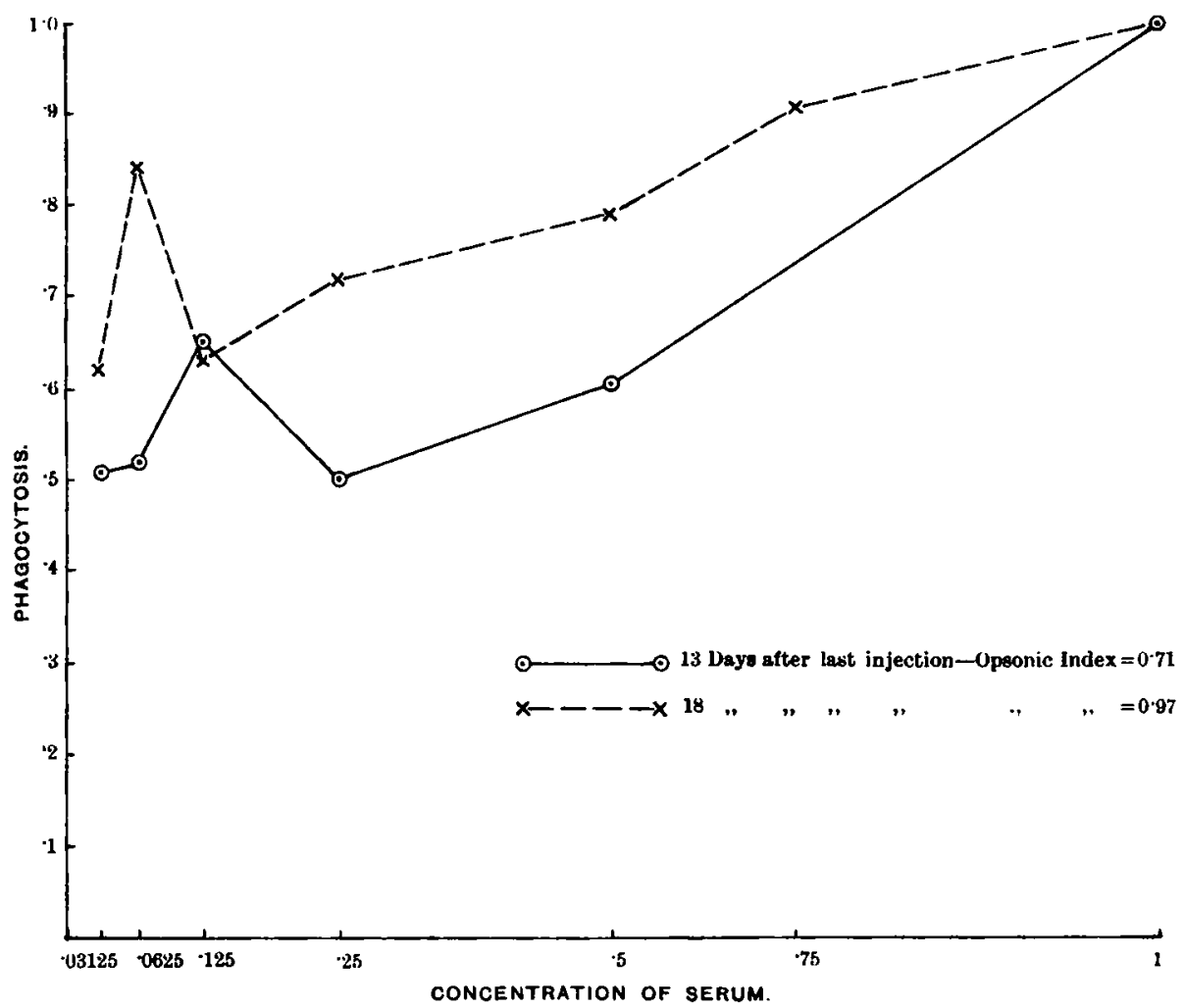

CHART VI.-Immune Rabbit B, showing the phagocytosis in the presence of various dilutions of the serum after numerous subcutaneous injections of killed 8taphylococcus pyogenes aureus. (1) Thirteen days after the last injection, and (2) eighteen dayg after the last injection. 


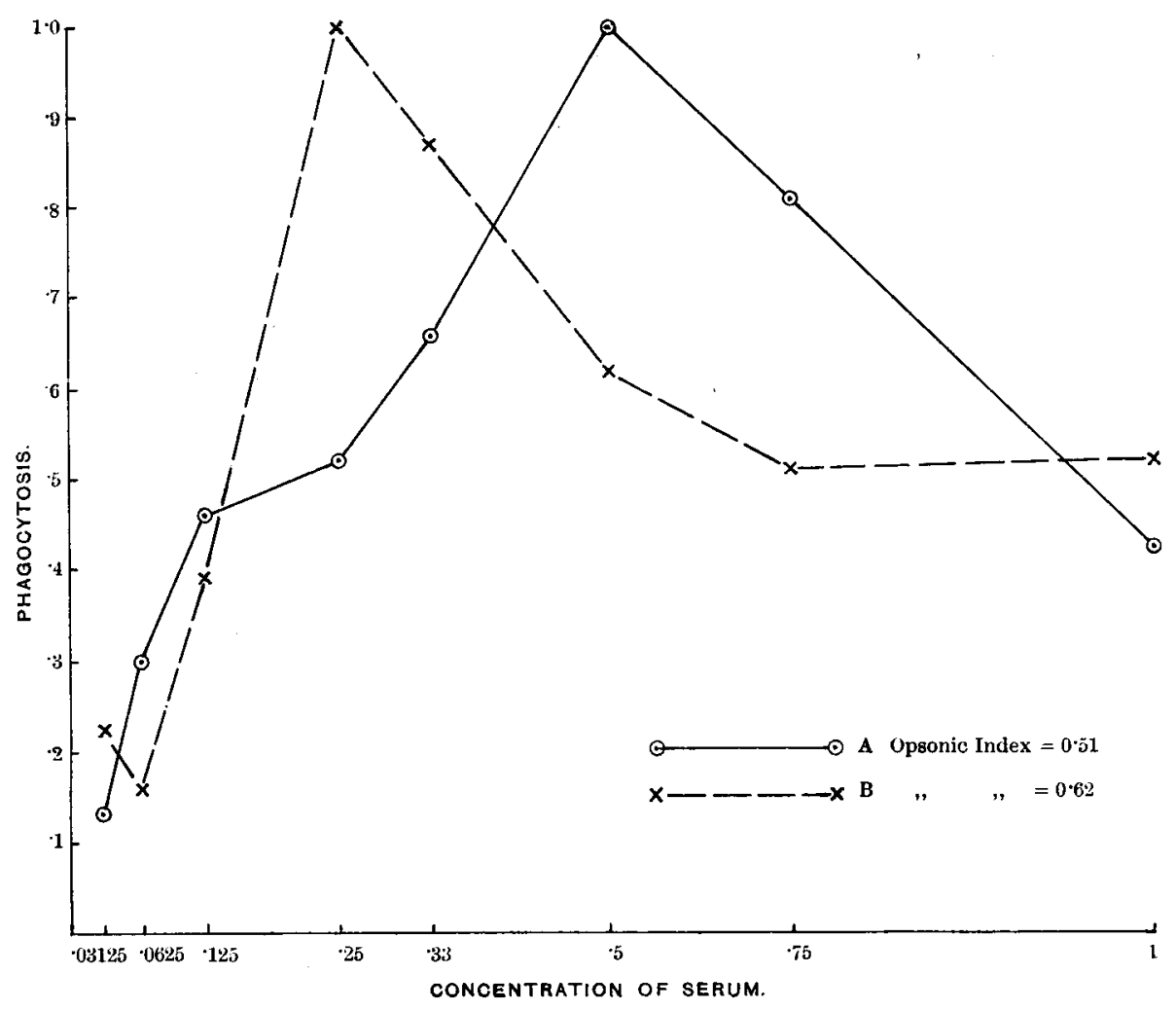

CHART VII.-Immune Horse " Rich," showing the phagocytosis in the presence of various dilutions of the serum of horse immunised by numerous injections of Staphylococcus pyogenes aureus during a period extending over two years. Bled on November 30, 1907 (A), and December 7, 1907 (B).

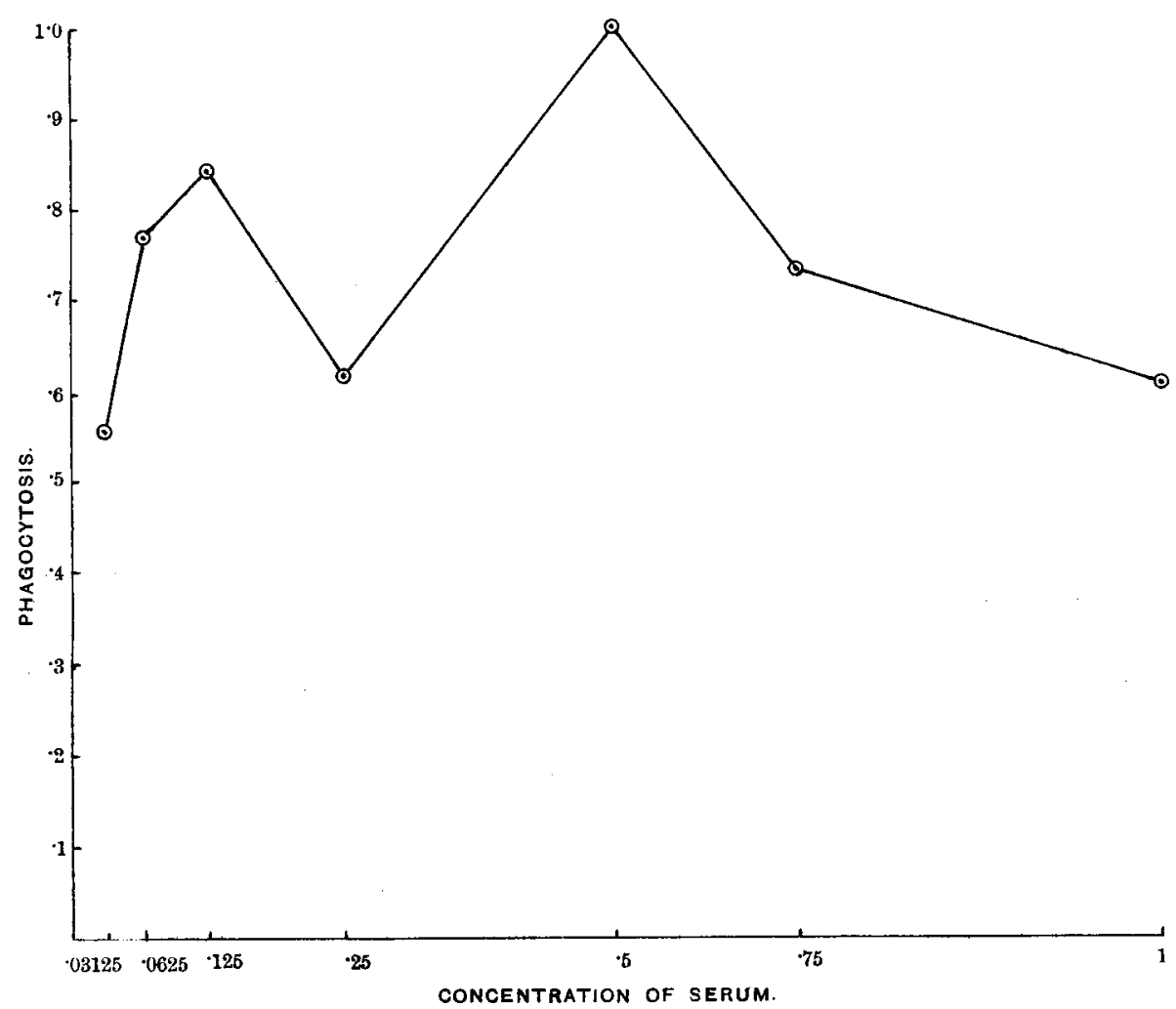

CHART VIII.-Immune Rabbit B, showing the phagocytosis in the presence of various dilutions of the serum after being heated to $60^{\circ} \mathrm{C}$. for twenty-five minutes. 


\section{REFERENCES.}

Dean . . . . . . Proc. Roy. Soc. London, B., 1907, rol. lxxix. p. 399.

Srmon, C. E., Lamar, R. V., " "A Contribution to the Study of the Opsonins," and Bisphan, W. R. Journ. Exper. Med., Baltimore, 1906, vol. viii. p. 6.51 .

\section{DESCRIPTION OF PLATES XXXVIII.-XLI.}

\section{Plate XXXVIII.}

CHART I. - Showing the influence on phagocytosis of various dilutions of the normal serum of the rabbit and of the ox.

ChanT II.-Rabbit $\mathrm{E}$, showing the phagocytosis in the presence of various dilutions of the serum twenty-four hours after intravenous injection with three agar tubes of killed Staphylococcus pyogenes aureus.

\section{PLATE XXXIX.}

Chart III. - Rabbit M, showing the phagocytosis in the presence of various dilutions of the serum after intravenous injection, on May 23, with five agar tubes of killed Staphylococcus pyogenes aurcus, and again on May 24, with three agar tubes. Bled May 25. Opsonic Index $=0 \cdot 70$.

CharT IV.-Rabbit $\mathrm{S}$, showing the phagocytosis in the presence of various dilutions of the serum one hour, five hours, and twenty-five hours after the intravenous injection with twelve agar trbes of killed Staphylococcus pyogenes aureus.

\section{Plate XL.}

CHART V. - Rabbit $Z$, showing the phagocytosis in the presence of various dilutions of the serum twenty hours after the intravenous injection with ten agar tubes of killed Staphylococcus pyogenes aureus. Opsonic Index for the tubercle bacillus $=0 \cdot 67$, and for the Stophylococcus pyogenes aureus $=1 \cdot 36$.

CH.ART VI.-Imnune Rabbit B, showing the phagocytosis in the presence of various dilu. tions of the serum after numerous subcutaneous injections of killed Staphylococeus pyoyenes aureus (1) thirteen days after the last injection, and (2) eighteen days after the last injection.

\section{Plate XLI.}

Chak'T VII.-Immune Horse (Rich), showing the phagocytosis in the presenee of various dilutions of the serum of horse immunised by numerous injections of Staphylococeus pyogenes aureus during a period extending over two years. Bled on November 30, 1907 (A), and December 7, 1907 (E).

CHAlR VIII.-Immune Rabbit B, showing the phagocytosis in the presence of various dilutions of the serum after being heated to $60^{\circ} \mathrm{C}$. for twenty-five minutes. 